\title{
Exchange Rate Volatility and Sectoral Analysis of Non-Oil Export in Nigeria
}

\author{
Lukman Oyeyinka Oyelami* \\ Omowumi M. Ajeigbe ${ }^{* *}$
}

\begin{abstract}
The paper seeks to assess the industry-based effect of exchange rate volatility on the export of non-oil sector in Nigeria. Theoretically and empirically, volatility-trade link is ambiguous. The paper employed bound test for co-integration between exchange rate volatility and exports of non-oil products. Empirically, the results show that we can accept the hypothesis of no co-integration between volatility and export of non-oil industries in most cases. Therefore, the study concludes that the exchange rate volatility can actually produce negative effect on non-oil export industries in the short-run especially the big industries (Agriculture, food and manufacturing) but this effect does not linger into the long-run and this suggests that most of these industries have been able to develop a mechanism to cope with exchange rate volatility problem in the long-run.
\end{abstract}

Keywords: Volatility; Non-oil; Export; Nigeria

JEL Classification: $\mathrm{F} 31, \mathrm{Q} 1, \mathrm{~F} 10, \mathrm{O} 5$

\section{Introduction}

Over the years, the Nigerian economy has been described as mono-economy that fundamentally relies on the export of crude oil for the bulk of its foreign earnings with little or no attention to the non-oil sector of the economy. In recent time, there have been serious advocacy for economic diversification but this has not yielded desired results as the government still counts heavily on revenue from oil for infrastructural financing and other basic responsibilities.

To achieve this diversification, non-oil sector of the economy has been identified as a viable alternative especially agriculture which was hitherto area of comparative

* Lukman Oyeyinka Oyelami is at University of Lagos, Lagos, Nigeria.

** Omowumi M. Ajeigbe is at Department of Economics, Redeemer's University Ede, Osun, NG 7914, Nigeria (ajeigbeo@run.edu.ng) 
advantage. However, the diversification efforts have not yielded substantial results. This necessitates the need to examine the role of the exchange rate as a major macroeconomic variable in the country. Consequently, studies have emanated to examine the contribution of exchange rate volatility to the performance of the non-oil sector of the Nigerian economy (Akinlo and Adejumo, 2014; Imoughele and Ismaila, 2015). What runs through most of these studies is the aggregation of exports of all non-oil industries without taken into consideration the peculiarities of different nonoil industry, whereas studies in other countries have gone beyond this aggregation. Also, many of these studies count on the traditional method of co-integration despite the mixed level of stationarity in their unit root results thus raising methodological issues. Basically, the study intends to investigate how exchange rate volatility affects non-oil export in Nigeria with specific attention to uniqueness of different industries both in the long-run and the short run.

In the literature of exchange rate volatility and trade flow, controversy exists both theoretically and empirically as regard how exchange rate volatility affects trade flows. In theoretical parlance, De Grauwe (1988) theoretically explains the reason exchange rate uncertainty could have positive or negative effects on the trade flows. $\mathrm{He}$ anchors his theory on behaviour under risk which prevents clear cut conclusion on the outcome of interaction between exchange rate volatility and trade flows. Also, empirically studies like Arize, Osang \& Slottje (2000) gives evidence of negative relationship between exchange rate volatility and trade but contrarily, McKenzie and Brooks (1997) gives evidence of positive relationship between exchange rate volatility and trade flows.

Based on this, there is still need for serious empirical investigations especially in a developing and mono economy country like Nigeria where over dependency on oil revenue has made the exchange rate a big macroeconomic problem. Given this general introduction, the part of the paper is organized thus. Section two gives general overview of exchange rate policy and export (oil and nonoil) sector of Nigerian economy, section three gives the review of extant literature while section four focuses on methodology of study and section five discusses the results and findings.

\section{Overview of Exchange Rate policy and Export (Oil and Nonoil) Sector of Nige- rian Economy}

According to the central bank of Nigeria, the objectives of exchange rate policy in the country are to preserve the value of the domestic currency, maintain a favourable external reserves position and ensure external balance without compromising the need for internal balance and the overall goal of macroeconomic stability. To achieve these aims, CBN has resorted to the adoption of different exchange regime raging from strictly pegged exchange rate to managed floating exchange rate. An incur- 
sion to the evolution of exchange policy overtime in Nigeria will require discussion of different exchange regime in the country. Also, for the purpose of the study the performances of oil and non-oil export are examined under different exchange rate policy régime. Generally, prior to the year 1986, there was a perpetual fixed exchange regime during the period and this will restrict our discussion to the period between 1986 and 2015.

Generally, figure one shows the natural logarithm value of oil and non-oil export and exchange rate in Nigeria for the period between 1986 and 2015. The period witnessed upward movement in Nigerian aggregate export oil and non-oil. Also, the exchange rate in the country has witnessed a tremendous increase during the same period though relatively stable between 2000 and 2014. It could be observed that there is a sharp co-movement in the in the three variables though there seem to be higher co-movement between exchange rate and oil export. Studies on determinants of the exchange rate and its volatility in Nigeria have somewhat established a strong link between oil export and exchange rate in Nigeria (Akpokodje, 2007; Yinusa \& Akinlo, 2014 and Ajao\& Igbekoyi, 2013). More importantly, the figure shows a wide gap between the oil and non-oil export as it maintains a contribution of more than $90 \%$ of aggregate export in the country throughout the period under consideration.

Figure 1: Oil, Non-oil export and Exchange Rate Movement in Nigeria (1986-2015)

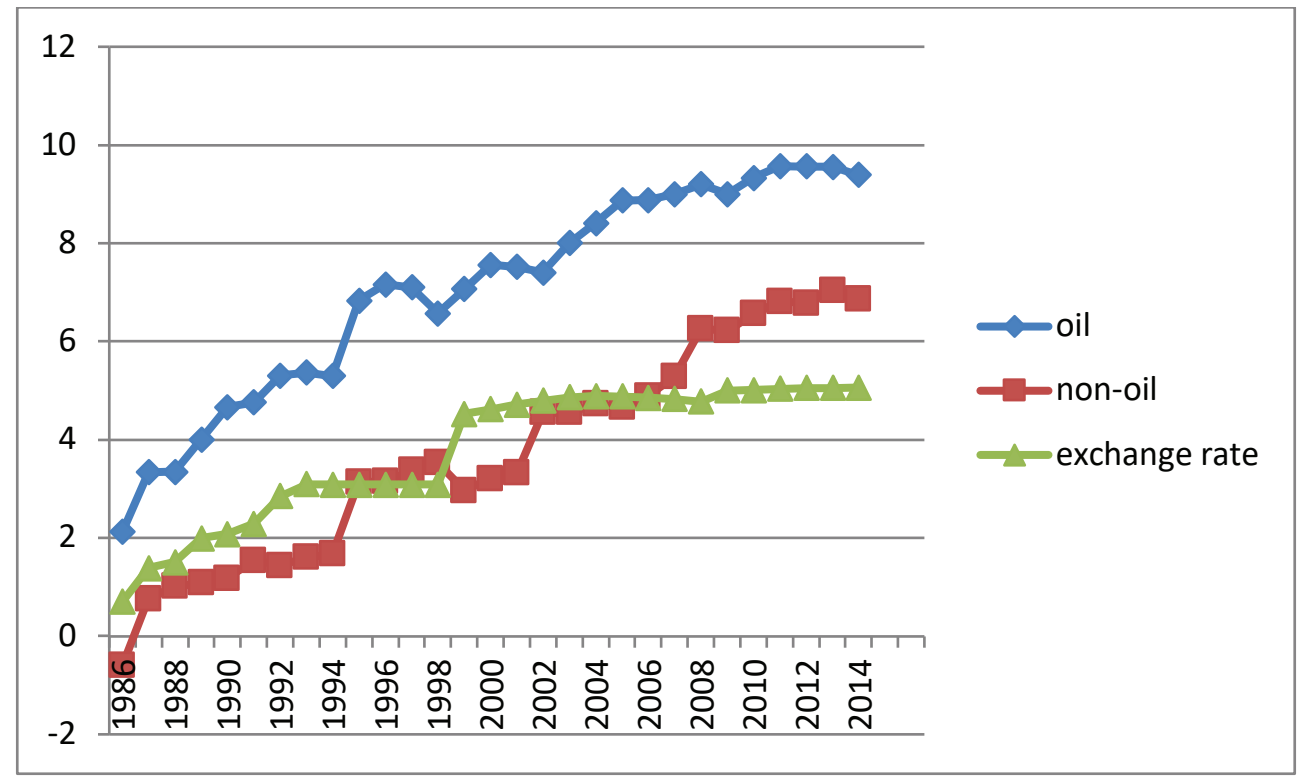

Source: Author's computation based on Central Bank Data (CBN) (1996-2015) 
SAP Era (1986-1993)

The policy commenced on September 1986. During this fixed exchange rate mechanism for determining the naira exchange rate was removed and replaced with a floating exchange rate mechanism. This system allowed the market forces of demand and supply of foreign exchange to determine the value of naira through monetary authority still retains the power to intervene in order to attain the policy objective. As expected, there was persistent depreciation of naira in the foreign exchange market. The first year of the policy (1986), the value of naira depreciated by $126.07 \%$ in the official market and $496.5 \%$ the subsequent year, throughout the policy period naira depreciated on the average of 147.5 per annual. This is reflected in the first phase of figure one that shows a persistent rise in the exchange rate, oil export and non-oil export.

\section{Post SAP Era (1994-1998)}

After the unsatisfactory performance of the economy during the structural adjustment programme, in 1994 there was policy reversal with the introduction of the regulated framework of rate policy. The policy lasted four years but there was a return to a liberalized framework of guided deregulation of the foreign exchange in 1999. As shown in figure one the period witnessed an oscillatory upward movement in the exchange rate and non-oil export thus suggests that non-oil export performed better under floating exchange rate but oil export seems to be independent of exchange rate movement.

\section{Post SAP Era (1999-2009)}

In 1999, the market-determined exchange rate was restored. The major element of the deregulated market was the reintroduction of Autonomous Market for Foreign Exchange (AFEM) for disbursing foreign exchange to end users through selected banks in 1995. As a compliment, Inter-Bank Foreign Exchange Market (IFEM) was introduced in 1999. However, the operation of the IFEM experienced similar problems and setbacks as the AFEM, owing to supply-side rigidities, the persistent expansionary fiscal policy of government and attendant problem of persistent excess liquidity in the system. From 16 July 2002, CBN has replaced IFEM with the Dutch Auction System (DAS) has been in operation with one form of regular modification till date. The performance of oil and non-oil export during this period can be adjudged to be fairly good as they witnessed a relative increase during this period. This is shown in figure one.

Apart from this global perceptive, it is clear from the analysis of percentage increase of oil export that the sub-sector has its up and down and it can be adduced that it is majorly influenced by the price of crude oil at the international market. The sub-sector experienced an increase of $237.08 \%$ in 1985 shortly after the introduction 
of the flexible exchange rate as a result of the structural adjustment programme but fell to just $0.8 \%$ in the following year. Similarly, the non-oil sector increased by $289.78 \%$ during the same period but nosedived to just $28.13 \%$ in the subsequent year. Afterwards, the percentage increase of oil export has not been consistent to the extent it produces negative value in some years and this is shown in figure two but despite this erratic performance, the sub-sector has done better than the non-oil sector.

Moving away from general aggregation, based on data obtained from the World Trade Organization (WTO) we examined the trend of non-oil export products from Nigeria and it is presented in figure two. The figure shows that non-oil export in Nigeria is dominated by agricultural products as the sector contributes on the average more than $20 \%$ of the total non-oil export annually this is followed by the manufacturing sector. In 1996 agriculture and food industries contribute more than $67 \%$ of the total non-oil export and this clearly depicts the primary nature of Nigerian non-oil export. In recent time, there seems to be a bit of improvement as the manufacturing industry is playing a leading role, this might not be unconnected with dwindling fortunes of the agriculture industry. More importantly, it is worthy of note that from 2006 there has been cyclical movement in revenue generated from each non- oil sector which typically mirrors the behaviour of other macroeconomic variables, especially exchange rate.

Figure 2: Nigerian Agricultural, Manufacturing, Services and Mining Exports in US Dollar (1996-2015)

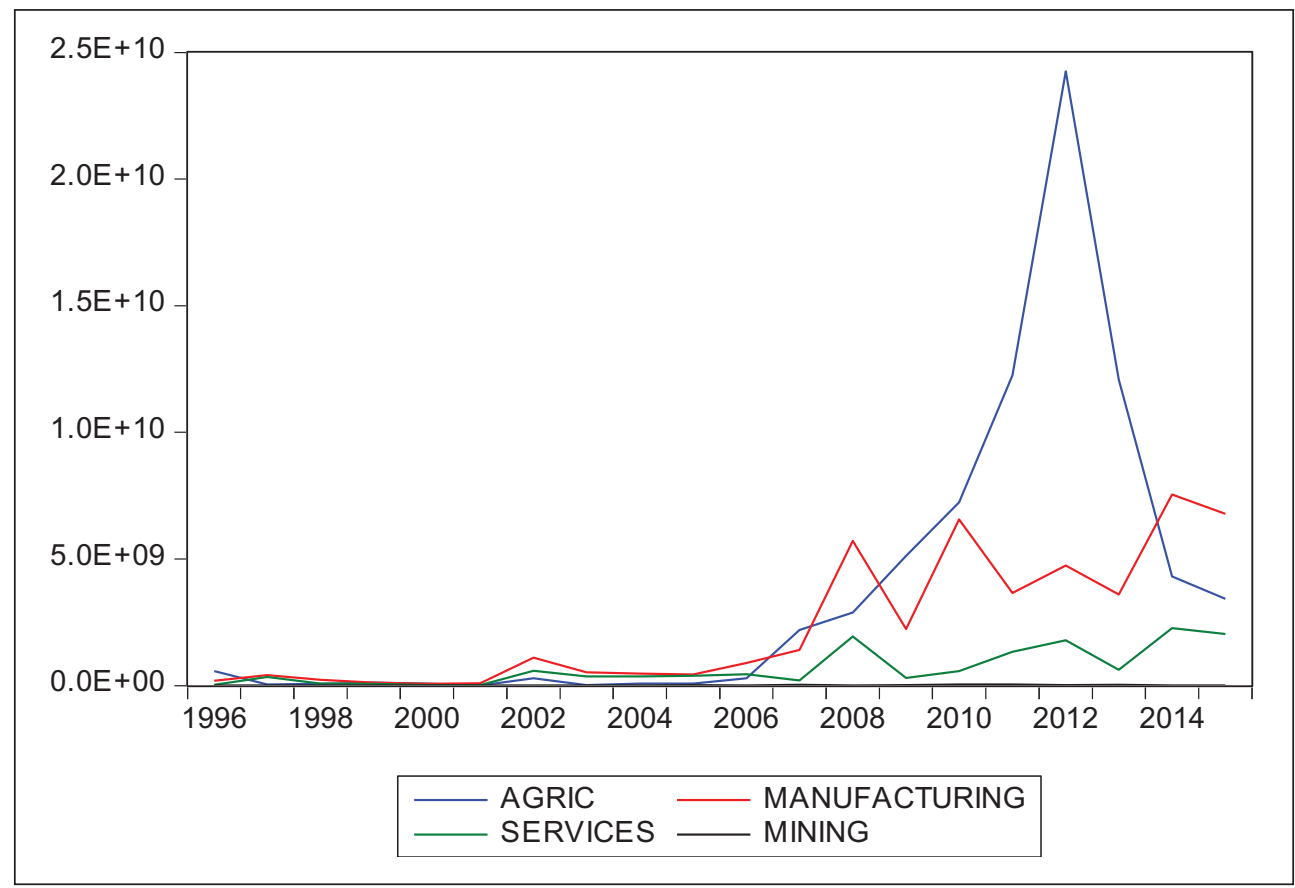

Source: Author's computation based on World Trade Organization WTO (1996-2015) 


\section{Empirical Literature}

The literature on exchange rate volatility and trade flow is rich and abundant both theoretically and empirically but for sake of this study we are focusing on recent empirical literature but for a more detailed review of literature, study by McKenzie (1999), Ozturk (2006) and Bahmani-Oskooee and Hagerty (2007) will be of help.

Starting with the study by Bahmani-Oskooee, Hagerty and Xi (2016) which the investigate the effect of exchange rate volatility between Yen versus US dollar and neighbouring currencies on trade relations between Japan and United State (US). The unique feature of the study is the incorporation of the third effect which allows for the introduction of the exchange rate of neighbouring countries to US dollar in the estimated model. The results from the study show that most industries in Japan are unaffected by the risk posed by exchange rate volatility. The reason for this result could be that Japan being a developed country has a vibrant financial market such that the risk posed by exchange rate volatility can easily be hedged by innovative financial market instruments and diversification of export base but such financial instruments and diversification opportunity are not available in many developing countries especially mono-economy country like Nigeria.

In another study by Asterious, Masatci and Pilbeam (2016) with a focus on Mexico, Indonesia, Nigeria, and Turkey (MINT) countries; they examine the effect of exchange volatility on international trade. Specifically, they analyse the effect of volatility on short-run import and export demand functions using both nominal and real exchange rate volatility. The results from the study show that volatility can significantly affect short-run import and export demand functions but not in the long run. Also, the results bring to bear that income elasticity for import and export demand differs significantly among the MINT countries though this is expected. The basic strength of this study is the introduction of short run and long run approach which hitherto has not been given adequate consideration.

Another similar study by Bahmani-Oskooee, Iqbal and Khan (2016) using the experiences of 57 Pakistan's exporting to and 52 importing industries from the US to estimate the effect of exchange rate volatility on trade flow. The data employed in the study is highly disaggregated thus provide room for more conflicting results in the study of this nature. The results indicate that even in the short run not all industries are affected by exchange rate volatility and not all the industries affected in the short run carry it over to the long run. Also, the results show that large can even take advantage of exchange volatility to expand trade.

In addition, several studies in Nigeria have examined the nexus that exists between exchange rate volatility and trade flow in general without any specific conclusion but very few studies have focused on non-oil export. Generally, Ojo (1978) suggested that exchange rate changes need not play any significant role in the explanation of Nigerian import-export balance without any serious empirical analysis and this po- 
sition is corroborated by Subsequent studies by Osagie (1985) and Ajayi (1988). The major influence on their studies might be linked to a fixed system of exchange that was being operated prior 1986 structural adjustment programme. But other studies by Osuntogun et al. (1993) and Egwaikhide (1993) have expressed contrary positions. Specifically, studies by Oyejide (1986), Omolola (1992), Akanji (1992), Adubi and Okunmadewa (1999) and Aliyu (2008) that focused more on non-oil export have come up with conclusion that exchange rate movement and its volatility can pose threat to non-oil export in Nigeria but mostly they fail to tell us whether the threat is in short run or long run.

Going by the recent trend in the literature of exchange rate volatility and trade, it is not enough to argue that exchange rate volatility has a negative or positive effect on trade flow but some clarifications must be made. These include whether the country involve is developed or developing country, whether the effect is in the short run or long run, whether industries involve are big or not and the nature of the products they trade in. With this, more complexities have been introduced into the nexus of exchange rate volatility and trade, thus any new study most take these complexities into consideration before a meaningful conclusion can be drawn from such study.

\section{Research Methodology}

\section{Data}

The data were obtained on quarterly basis for exchange rate, GDP and Inflation for the period 1996-2015 while data on sectoral export were on annual basis but later converted to quarterly data using quadratic sum from e-view package for the same period.

\section{Model Estimation}

In line with similar studies in this area especially, Goldstein \& Khan, (1976), we adapted a model that provides space for introduction of exchange volatility and other control variables with value of export as dependent variable. Specifically, we estimated this model within the framework of ARDL.

$$
\begin{aligned}
& \Delta \ln \text { NOIL }_{t}=\lambda_{0}+\sum_{j=1}^{n 1} \lambda_{i} \Delta \ln \text { Noil }_{t-1}+\sum_{j=1}^{n 1} \lambda_{2} \Delta \ln G D P_{t-i}^{\text {world }}+\sum_{j=1}^{n 2} \lambda_{3} \Delta \ln \text { PRICE }_{t-i} \\
& +\sum_{j=1}^{n 3} \lambda_{4} \Delta \ln \text { Vol }_{t-i}+\theta_{1} \ln G D P_{t=i}^{\text {world }}+\theta_{2} \ln \text { PRICE }_{t=i}+\theta_{3} \ln V O L_{t=i}+\varepsilon_{t}
\end{aligned}
$$

In equation one, both short-run (first-differenced) and long-run (one-period-lagged level) variables are incorporated. In the case of short-run coefficients, lag length is 
selected based on Akaike Information Criterion (AIC), and each model is estimated based on the selected optimum lags. In the model presented, $N O I L_{t}$ is the value of all non-oil products exported from Nigeria, $P R I C E_{t-i}$ is the relative price between Nigeria and the world, GDP ${ }_{t-i}^{\text {world }}$ is the level of income from trading partners and $V o l_{t-i}$ is the exchange rate volatility specifically obtained from parallel market because official exchange rate in the country has been not substantially supported to be volatile unlike parallel market.

As part of the requirement for ARDL and GARCH models, integration properties of our data were tested using unit root tests and the results are presented in table one and two. The results indicate that variables are mixture of integration of order zero I(0) and one I(1). Specifically, Augmented Dickey Fuller unit test in Table 1 shows that the exchange rate in two markets (inter-bank and BDC) are integrated of order one I(1) also, export from different non-oil subsector exhibits different order of integration but majorly they are predominantly integrated of order one I(1). Similarly, control variables such as relative price and economy of trading partners represented by their GDP growth rate are integrated of order one I(1). The results from Phillips-Peron (PP) unit root test in Table 2 as well, 5 shows that in model variables are of different level of integration I(0) and I(1).

Table 1: Augmented Dickey Fuller unit test

\begin{tabular}{|c|c|c|c|c|c|c|}
\hline \multicolumn{3}{|c|}{ Level } & \multirow[b]{2}{*}{ None } & \multirow[b]{2}{*}{ Constant } & \multirow[b]{2}{*}{$\begin{array}{l}\text { Constant } \\
\text { and Trend }\end{array}$} & \multirow{2}{*}{$\begin{array}{c}\begin{array}{c}\text { First } \\
\text { Difference }\end{array} \\
\text { None }\end{array}$} \\
\hline Variables & Constant & $\begin{array}{l}\text { Constant } \\
\text { and Trend }\end{array}$ & & & & \\
\hline Agric. Products & 2.114 & -2.633 & -1.696 & $-4.355 * * *$ & $-4.343 * * *$ & $-4.359 * * *$ \\
\hline Automotive & -1.640 & -1.776 & -1.017 & $-7.384 * * *$ & $-7.385^{* * *}$ & $-7.395 * * *$ \\
\hline Chemicals & -1.635 & -1.705 & -1.106 & $-5.388 * * *$ & $-5.399 * * *$ & $5.396^{* * * *}$ \\
\hline Clothing & $-3.447 * *$ & $-3.505^{* *}$ & $-2.693 * *$ & & & \\
\hline Electronic & -2.106 & -2.100 & -1.543 & $-6.667 * * *$ & $-6.674 * * *$ & $-6.682 * * *$ \\
\hline Food & -1.338 & -2.262 & -0.849 & $-5.520 * * *$ & $-5.511 * * *$ & $-5.520 * * *$ \\
\hline Iron \&Steel & -1.313 & -1.486 & -0.698 & $-5.913 * * *$ & $-5.921 * * *$ & $-5.922 * * *$ \\
\hline Machinery\&Transport & -0.532 & -2.802 & 0.429 & $-6.872 * * *$ & $-6.907 * * *$ & $-6.793 * * *$ \\
\hline Manufactures & -0.345 & -2.265 & 0.682 & $-5.336 * * *$ & $-5.340 * * *$ & $-5.145^{* * *}$ \\
\hline Office \& Telecom. Equip & -2.085 & -2.036 & -1.275 & $-6.939 * * *$ & $-6.952 * * *$ & $-6.953 * * *$ \\
\hline Pharmaceuticals & -1.707 & -2.075 & -0.946 & $-5.324 * * *$ & $-5.301 * * *$ & $-5.312 * * *$ \\
\hline Telecom.Equip. & -3.947 & -3.978 & -2.605 & & & \\
\hline Textiles & 0.232 & -1.124 & 0.866 & $-6.098 * * *$ & $-6.284 * * *$ & $-4.541 * * *$ \\
\hline Transport_Equipment & -0.994 & -3.186 & -0.045 & $-6.771 * * *$ & $-6.784 * * *$ & $-6.734 * * *$ \\
\hline $\mathrm{BDC}$ & 1.501 & 0.053 & 2.395 & $-10.471 * * *$ & $-10.627 * * *$ & $-10.194 * * *$ \\
\hline INTER-BANK & 0.147 & -1.874 & 2.515 & $-14.41 * * *$ & $-14.417 * * *$ & $-14.083 * * *$ \\
\hline
\end{tabular}




\begin{tabular}{|l|c|c|c|c|c|c|}
\hline \multicolumn{2}{|c|}{ Level } & & \multicolumn{2}{l|}{} & $\begin{array}{c}\text { First } \\
\text { Difference }\end{array}$ \\
\hline Variables & Constant & $\begin{array}{c}\text { Constant } \\
\text { and Trend }\end{array}$ & None & Constant & $\begin{array}{c}\text { Constant } \\
\text { and Trend }\end{array}$ & None \\
\hline GDP & -0.280 & -2.144 & 2.146 & $-3.796 * * *$ & $-3.742 * * *$ & $-2.844 * * *$ \\
\hline Price & -2.323 & -2.264 & -0.531 & $-4.116^{*} * *$ & $-4.092 * * *$ & $-4.133 * * *$ \\
\hline CV 1\% & -3.490 & -4.043 & -2.586 & -3.490 & -4.043 & -2.586 \\
\hline CV 5\% & -2.887 & -3.451 & -1.943 & -2.887 & -3.451 & -1.943 \\
\hline CV 10\% & $\mathbf{- 2 . 5 8 0}$ & $\mathbf{- 3 . 1 5 0}$ & $\mathbf{- 1 . 6 1 4}$ & $\mathbf{- 2 . 5 8 0}$ & $\mathbf{- 3 . 1 5 0}$ & $\mathbf{- 1 . 6 1 4}$ \\
\hline
\end{tabular}

Note:***,**,*indicate significant at $1 \%, 5 \%$ and $10 \%$

Source: Author's computation

Table 2: Phillips-Peron (PP) unit root test

\begin{tabular}{|c|c|c|c|c|c|c|}
\hline \multicolumn{3}{|c|}{ Level } & & \multicolumn{2}{|c|}{ First } & \multirow[b]{2}{*}{ None } \\
\hline Variables & Constant & $\begin{array}{l}\text { Constant } \\
\text { and Trend }\end{array}$ & None & Constant & $\begin{array}{c}\text { Constant } \\
\text { and Trend }\end{array}$ & \\
\hline Agric. Products & -1.668 & -1.955 & -1.352 & $-10.408 * * *$ & $-10.394 * * *$ & $-10.417 * * *$ \\
\hline Automotive & $-2.898 * *$ & $-3.232 * *$ & $-2.321 * *$ & & & \\
\hline Chemicals & -2.617 & -2.882 & -2.107 & $-12.327 * * *$ & $-12.308 * * *$ & $-12.347 * * *$ \\
\hline Clothing & $-2.894 * *$ & $-2.946 * *$ & $-2.617 * *$ & & & \\
\hline Electronic & $-3.122 * *$ & $-3.205 * *$ & $-2.663 * *$ & & & \\
\hline Food & -1.831 & -2.398 & -1.404 & $-11.877 * * *$ & $-11.858 * * *$ & $-11.890 * * *$ \\
\hline Iron \&Steel & -1.895 & -2.431 & -1.324 & $-11.985 * * *$ & $-11.966 * * *$ & $-12.003 * * *$ \\
\hline Machinery\&Transport & -2.091 & -3.531 & -1.238 & $-12.114 * * *$ & $-12.093 * * *$ & $-12.130 * * *$ \\
\hline Manufactures & -1.733 & -3.355 & -0.921 & $-12.392 * * *$ & $-12.370 * * *$ & $-12.400 * * *$ \\
\hline Office \& Telecom. Eqp & -3.180 & -3.282 & -2.443 & $-12.436 * * *$ & $-12.416 * * *$ & $-12.456 * * *$ \\
\hline Pharmaceuticals & -3.093 & -3.422 & -2.479 & $-12.523 * * *$ & $-12.505 * * *$ & $-12.539 * * *$ \\
\hline Telecom.Equip. & -3.267 & -3.277 & -2.493 & $-12.156 * * *$ & $-12.136 * * *$ & $-12.176^{* * * *}$ \\
\hline Textiles & -1.503 & -2.485 & -0.997 & $-11.729 * * *$ & $-11.713 * * *$ & $-11.738 * * *$ \\
\hline Transport_Equipment & -2.377 & -3.628 & -1.513 & $-12.155^{* * *}$ & $-12.134 * * *$ & $-12.172 * * *$ \\
\hline $\mathrm{BDC}$ & 1.883 & 0.467 & 2.646 & $-10.547 * * *$ & $-10.638 * * *$ & $-10.222 * * *$ \\
\hline INTER-BANK & 0.0823 & -2.082 & 2.431 & $-14.413 * * *$ & $-14.417 * * *$ & $-14.116^{* * * *}$ \\
\hline \multicolumn{7}{|l|}{ GDP } \\
\hline \multicolumn{7}{|l|}{ Price } \\
\hline CV $1 \%$ & -3.492 & -4.046 & -2.586 & -3.49374 & -4.047795 & -2.587 \\
\hline CV 5\% & -2.888 & -3.452 & -1.9438 & -2.88920 & -3.453179 & -1.943 \\
\hline CV $10 \%$ & -2.581 & -3.151 & -1.614 & -2.581 & -3.152 & -1.614 \\
\hline
\end{tabular}

Note: $* * *, * *, *$ indicate significant at $1 \%, 5 \%$ and $10 \%$

Source: Author's computation 


\section{Selection of GARCH Model}

The issues around exchange rate volatility have received serious attention in the literature and it still receiving attention particularly on the best proxy to show volatility. Majorly, three different measures have been employed to represent the volatility of exchange rates. Dell'Ariccia (1999) employs the standard deviation of the first difference of the log real exchange rate while Bun and Klassen (2004) measure exchange rate volatility using the moving average standard deviation of the monthly logarithm of the real exchange rate. In more recent time, ARCH/GARCH modeling has been popularly employed for modeling volatility, a study by Sauer and Bohara (2001), and DeVita and Abbott (2004) provide good treatment of the model.

In applying the GARCH models to capture the volatility of exchange rates, two steps have been generally considered to be very important. The first step borders on the stationarity of the data employed for the GARCH model while the second step focuses on the optimal lag selection of the GARCH model. As reported earlier, we carried out unit root test on all the data employed in our model especially nominal exchange rate at inter-bank and bureau de change. Before selecting an optimal lag length for our models, we considered testing for the presence of ARCH effect in both inter-bank exchange rate and the parallel market rate as so determining which of the two rates is volatile. This is important because not all sectors of the Nigerian economy have access to the official exchange rate for trading activities thus, it is crucial to examine what happens in the parallel market which provides access to Forex in the country. The results of these tests are presented in table 3. The results from the models show that there that the hypothesis of homoscedasticity is rejected for the exchange rate in the parallel market while the same hypothesis is accepted for exchange rate at the inter-bank market. Based on these results, it safe to conclude that there is the presence of volatility clustering only in parallel market exchange rate not in official market rate. This corroborates earlier study in this area (Yinusa 2008).

Furthermore, to select an optimal lag length for our GARCH model, we used the Akaike (AIC) and the Schwartz (SIC) information criteria as model selection tools. As shown in Table 4, the model that produces minimum AIC and SIC values were selected and are GARCH $(2,3)$. To validate the suitability of the model, we tested for ARCH effect and serial autocorrelation using ARCH LM tests. The results show that we can accept the null hypothesis of no ARCH effect and no serial correlation in the model. 
Table 3: Heteroskedasticity Test: ARCH

\begin{tabular}{|l|l|l|c|}
\hline \multicolumn{5}{|c|}{ Parallel Market } \\
\hline F-statistic & 9.096935 & Prob. F $(1,235)$ & 0.0028 \\
\hline Obs*R-squared & 8.832448 & Prob. Chi-Square $(1)$ & 0.0030 \\
\hline \multicolumn{5}{|c|}{ Official Market } \\
\hline F-statistic & 0.023569 & Prob. F $(1,236)$ & 0.8781 \\
\hline Obs*R-squared & 0.023767 & Prob. Chi-Square(1) & 0.8775 \\
\hline
\end{tabular}

Source: Author's computation

Table 4: GARCH $(2,3)$

\begin{tabular}{|l|c|c|c|c|}
\hline \multicolumn{1}{|c|}{ Variable } & Coefficient & Std. Error & z-Statistic & Prob. \\
\hline C & 0.002916 & 0.000910 & 3.203159 & 0.0014 \\
\hline & Variance Equation & & & \\
\hline C & $6.27 \mathrm{E}-06$ & $1.04 \mathrm{E}-06$ & 6.033239 & 0.0000 \\
\hline RESID(-1)^2 & 0.395902 & 0.005445 & 72.71275 & 0.0000 \\
\hline RESID(-2)^2 & -0.416465 & 0.003392 & -122.7904 & 0.0000 \\
\hline GARCH(-1) & 1.044596 & 0.000453 & 2303.751 & 0.0000 \\
\hline GARCH(-2) & 0.296602 & 0.017734 & 16.72478 & 0.0000 \\
\hline GARCH(-3) & -0.329617 & 0.019021 & -17.32916 & 0.0000 \\
\hline
\end{tabular}

Source: Author's computation

\section{Model Estimation}

Based on the mixed level of stationarity from unit root tests, we considered it necessary to perform the co-integration test with the view to determining if there exists a long-term relationship in our variables for estimation. In economic literature, there are two approaches to cointegration analysis, the Engle and Granger (1987) two-step process and maximum likelihood reduced-rank procedure by Johansen (1988). Based on DeVita and Abbott (2004) argument, in the presence of a mixed order of integration, I (0) and I(1), standard statistical inference based on conventional cointegration tests is no longer valid. However, the ARDL bound testing technique proposed by Pesaran and Shin (1999) can take care of the situation because it does not require that all the variables be integrated of the same order.

The procedure of ARDL bound testing as proposed by Pesaran and Shin (1999), involves the use of F-statistic for the joint significance of the estimators of the lagged levels in the model to test the null hypothesis of "no cointegration". Pesaran and Shin (1999) present two asymptotic critical values: the lower value and the upper value. Lower value assumes that all variables are $\mathrm{I}(0)$ while the upper value assumes that all 
variables are I(1). If the calculated test statistic exceeds the upper critical value, then the null hypothesis of "no cointegration" is rejected. If it is within the lower bound, the null cannot be rejected. In a situation where it statistic falls within the respective bounds, it makes cointegration test inconclusive.

In this study, we include the volume of export of different non-oil industries from Nigerian economy together with relative prices of import and export and level of income of important trading partners in our model proxy by their GDP. Furthermore, we carried out a cointegration test Industry by Industry. The results as reported in table 5 are mixed; the results indicate that five out of fourteen industries considered show evidence of cointegration while the remaining nine show evidence of no cointegration. Explicitly, Clothing, Electronic Data Processing, Machinery and Transport, Manufacturing and telecommunication equipment industries show pieces of evidence of cointegration while industries like agriculture, food, Iron and steel, automobile, textile, Pharmaceuticals, transport equipment, chemicals, and office equipment show pieces of evidence of no cointegration. What are discernable from these results is that virtually all the industries where Nigeria seems not to have comparative advantage show evidence of cointegration. This suggests that most of these industries produced their products without adequate local contents and this makes them more vulnerable to exchange rate shocks compared to other industries where the country has a comparative advantage.

Also, table $6 \mathrm{a}$ and $6 \mathrm{~b}$ show the results of long and short run coefficient of non-oil export industries. Based on cointegration results, the industries are divided into two, table $6 \mathrm{a}$ comprises of industries without evidence of any cointegration and table $6 \mathrm{~b}$ comprises of industries with evidence of cointegration. From table 6a, the results show that the effect of exchange rate volatility on non-oil export is mixed and it depends on the industry. In the short-run, out of nine industries without evidence of any cointegration, exchange rate volatility has a negative effect on five industries (Agriculture, Chemical, Food, Iron and still and transport equipment) out which only two are statistically significant (Agriculture and Food). In the same table, the results show that volatility has a positive effect on four industries (Automobile, Telecom, Pharmaceutical, and textile) out which one is statistically significant (office and telecom equipment). Also, in the long run, the results produce mixed evidence as regards whether the effect of volatility is negative or positive. But the major concern is that virtually all of them do not have a statistically significant long-term relationship with volatility excerpt iron and steel industry.

From table 6b, which comprises of industries with evidence of cointegrations, the results are not substantially different from another category. In short-run, exchange rate volatility has both positive and negative effects on non-oil export depending on the industry. Volatility has a negative effect on Manufacturing, Machinery\& transport industries and Telecommunications Equip but only that of Manufacturing and Telecommunications Equip industries are statistically significant. On the other hand, 
volatility shows a positive effect on export of clothing and Electronic data processing industries but only that of telecommunication equipment industry is statistically significant. Despite the fact that the industries in this category show evidences of cointegration, exchange rate volatility has a statistically significant negative effect on only one industry (manufacturing) in long-run.

Table 5a: Bound tests Cointegration

\begin{tabular}{|l|c|c|c|c|}
\hline \multicolumn{1}{|c|}{ Product } & F-Statistics & $\begin{array}{c}\text { lower critical } \\
\text { value5\% }\end{array}$ & $\begin{array}{c}\text { Upper critical } \\
\text { value 5\% }\end{array}$ & Cointegrated \\
\hline AGRICULTURAL_PRODUCTS & 2.04 & 3.79 & 4.85 & No \\
\hline AUTOMOTIVE_PRODUCTS & 3.40 & 3.79 & 4.85 & No \\
\hline CHEMICALS & 2.36 & 3.79 & 4.85 & No \\
\hline FOOD & 3.94 & 3.79 & 4.85 & No \\
\hline IRON_AND_STEEL & 2.58 & 3.79 & 4.85 & No \\
\hline OFFICE_AND_TELECOM_EQUIP & 3.45 & 3.79 & 4.85 & No \\
\hline PHARMACEUTICALS & 1.49 & 3.79 & 4.85 & No \\
\hline TEXTILES & 3.01 & 3.79 & 4.85 & No \\
\hline TRANSPORT_EQUIPMENT & 4.36 & 3.79 & 4.85 & No \\
\hline
\end{tabular}

Source: Author's computation

Table 5b: Bound tests Cointegration

\begin{tabular}{|l|c|c|c|c|c|}
\hline CLOTHING & 5.08 & 3.79 & 4.85 & Yes \\
\hline ELECTRONIC_DATA_PROCESSING & 34.73 & 3.79 & 4.85 & Yes \\
\hline MACHINERY_AND_TRANSPORT & 52.11 & 3.79 & 4.85 & Yes \\
\hline MANUFACTURES & 6.42 & 3.79 & 4.85 & Yes \\
\hline TELECOMMUNICATIONS_EQUIP & 52.68 & 3.79 & 4.85 & Yes \\
\hline
\end{tabular}

Source: Author's computation 
Table 6a: Long and short run co-efficient of non-oil export industries

\begin{tabular}{|l|c|c|c|c|c|c|c|c|}
\hline Product & dlnvol $_{\mathrm{t}}$ & dlnvol $_{\mathrm{t}-1}$ & dlnvolt-2 & dlnvolt-3 & Constant & Inprice & Ingdp & Invol \\
\hline AGRICULTURAL_- & -2.20 & & & & -40.9 & -1.7 & 7.51 & -40.34 \\
PRODUCTS & $(0.03)$ & & & & $(0.001)$ & $(0.43)$ & $(0.00)$ & $(0.08)$ \\
\hline AUTOMOTIVE_ & 1.17 & & & & -23.64 & -0.41 & 4.80 & -4.79 \\
PRODUCTS & $(0.26)$ & & & & $(0.01)$ & $(0.79)$ & $(0,00)$ & $(0.78)$ \\
\hline \multirow{2}{*}{ CHEMICALS } & -0.92 & & & & -24.15 & -0.38 & 5.16 & -12.33 \\
& $(0.49)$ & & & & $(0.03)$ & $(0.86)$ & $(0.00)$ & $(0.50)$ \\
\hline \multirow{2}{*}{ FOOD } & 0.29 & -1.22 & 2.11 & 1.90 & -40.28 & -1.57 & 7.48 & -49.95 \\
& $(0.73)$ & $(0.18)$ & $(0.02)$ & $(0.03)$ & $(0.00)$ & $(0.34)$ & $(0.00)$ & $(0.14)$ \\
\hline \multirow{2}{*}{ IRON_AND_STEEL } & -0.63 & & & & -26.03 & 4.23 & 4.23 & 5.24 \\
& $(0.51)$ & & & & $(0.00)$ & $(0.00)$ & $(0.00)$ & $(0.00)$ \\
\hline OFFICE_AND_ & 0.36 & -4.14 & & & -6.84 & -0.45 & 2.57 & 63.12 \\
TELECOM_EQUIP & $(0.84)$ & $(0.03)$ & & & $(0.68)$ & $(0.86)$ & $(0.21)$ & $(0.14)$ \\
\hline \multirow{2}{*}{ PHARMACEUTICALS } & 0.14 & & & & -32.40 & 3.96 & 5.78 & 3.86 \\
& $(0.92)$ & & & & $(0.27)$ & $(0.44)$ & $(0.11)$ & $(0.92)$ \\
\hline \multirow{2}{*}{ TEXTILE } & 0.27 & & & & -19.45 & -0.03 & 4.74 & -22.90 \\
& $(0.60)$ & & & & $(0.03)$ & $(0.98)$ & $(0.00)$ & $(0.22)$ \\
\hline TRANSPORT_ & -0.30 & & & & -5.49 & 0.83 & 3.14 & -2.63 \\
EQUIPMENT & $(0.78)$ & & & & $(0.40)$ & $(0.45)$ & $(0.00)$ & $(0.78)$ \\
\hline
\end{tabular}

Source: Author's computation

Table 6b: Long and short run co-efficient of non-oil export industries

\begin{tabular}{|l|c|c|c|c|c|c|c|c|}
\hline CLOTHING & $\begin{array}{c}0.54 \\
(0.76)\end{array}$ & & & & $\begin{array}{c}0.68 \\
(0.94)\end{array}$ & $\begin{array}{c}6.05 \\
(0.00)\end{array}$ & $\begin{array}{c}1.67 \\
(0.13)\end{array}$ & $\begin{array}{c}4.14 \\
(0.76)\end{array}$ \\
\hline ELECTRONIC_DATA_ & 1.43 & & & & -22.21 & 1.87 & 4.39 & 11.40 \\
PROCESSING & $(0.54)$ & & & & $(0.08)$ & $(0.37)$ & $(0.00)$ & $(0.55)$ \\
\hline MACHINERY_AND_ & -0.05 & & & & -8.33 & 0.36 & 3.50 & -0.54 \\
TRANSPORT & $(0.95)$ & & & & $(0.24)$ & $(0.75)$ & $(0.00)$ & $(0.95)$ \\
\hline MANUFACTURES & -1.00 & 1.33 & 2.23 & & -14.75 & -1.71 & 4.35 & -56.78 \\
& $(0.22)$ & $(0.12)$ & $(0.00)$ & & $(0.01)$ & $(0.12)$ & $(0.00)$ & $(0.00)$ \\
\hline TELECOMMUNICATIONS_ & 0.65 & -2.42 & 3.09 & -2.64 & -2.36 & -2.36 & 1.83 & 22.79 \\
EQUIP & $(0.66)$ & $(0.13)$ & $(0.04)$ & $(0.85)$ & $(0.35)$ & $(0.35$ & $(0.29)$ & $(0.55)$ \\
\hline
\end{tabular}

Source: Author's computation

\section{Conclusion and Policy Recommendation}

The conclusion from this study is that the effect of exchange rate on non-oil export in Nigeria is industry specific but on the average in short-run the size of industry seems to matter as Agriculture, Food and Manufacturing that contribute more than 50\% of total non-oil export show negative responses to exchange rate volatility while small- 
er industries show positive responses to the same variables. In the long run, exchange rate volatility does not have any significant effect on exports of non-oil industries in the country except for the manufacturing sector where the country seems not to have a comparative advantage. In summary, the exchange rate volatility can actually affect non-oil export in the short-run especially the big industries but this effect does not dovetail into the long-run and this suggests that most of these industries have been able to develop a mechanism to cope with exchange rate volatility problem.

The policy recommendation from this study is that the country should focus more on export from the sector where there is a comparative advantage such agriculture and food because they do not show a significant response to exchange rate volatility in the long-run. The further empirical investigation will be advised at the industry level for other important determinants of non-oil export in the country.

\section{REFERENCES}

Adubi, A. A., \& Okunmadewa, F. (1999). Price, exchange rate volatility and Nigeria's agricultural trade flows: A dynamic analysis (No. RP_087). African Economic Research Consortium.

Ajao, M. G., \& Igbekoyi, O. E. (2013). The determinants of real exchange rate volatility in Nigeria. Academic Journal of Interdisciplinary Studies, 2(1), 459-471.

Ajayi, S. I. (1988). Issues of overvaluation and exchange rate adjustment in Nigeria. Prepared for Economic Development Institute (EDI), the World Bank, Washington, D.C.

Akanji, B. (1992). Cocoa marketing under Nigeria's structural adjustment programme. Nigerian Institute of Social and Economic Research.

Akinlo, A. E., \& Adejumo, V. A. (2014). Exchange Rate Volatility and Non-oil Exports in Nigeria: 1986-2008. International Business and Management, 9(2), 70-79.

Akpokodje, G. O. (2007). Exchange rate volatility and external trade performance of selected African countries, 1973-2003. A Ph. D thesis submitted to University of Ibadan, Nigeria.

Aliyu, S. (2008). Bilateral trade talk between Nigeria and India: a recipe. University Library of Munich, Germany.

Arize, A. C., Osang, T., \& Slottje, D. J. (2000). Exchange-rate volatility and foreign trade: evidence from thirteen LDC's. Journal of Business \& Economic Statistics, 18(1), 10-17.

Asteriou, D., Masatci, K., \& P1lbeam, K. (2016). Exchange rate volatility and international trade: International evidence from the MINT countries. Economic Modelling, 58, 133-140.

Bahmani-Oskooee, M., \& Hegerty, S. W. (2007). Exchange rate volatility and trade flows: a review article. Journal of Economic Studies, 34(3), 211-255.

Bahmani-Oskooee, M., Hegerty, S. W., \& Xi, D. (2016). Third-country exchange rate volatility and Japanese-US trade: evidence from industry-level data. Applied Economics, 48(16), 1452-1462.

Bahmani-Oskooee, M., Iqbal, J., \& Khan, S. U. (2016). Impact of exchange rate volatility on the commodity trade between Pakistan and the US. Economic Change and Restructuring, 1-27.

Bun, M. J., F. J.G.M. Klassen, 2004. The Euro Effect on Trade is not as Large as Commonly Thought. Tibergen Institute Discussion Paper 2003-086/2.

De Grauwe, P. (1988). Exchange rate variability and the slowdown in growth of international trade. Staff Papers, 35(1), 63-84.

De Vita, G., \& Abbott, A. (2004). Real exchange rate volatility and US exports: an ARDL bounds testing approach. Economic Issues, 9(1), 69-78. 
Dell'Ariccia, G. (1999). Exchange rate fluctuations and trade flows: Evidence from the European Union. IMF Economic Review, 46(3), 315-334.

Engle, R. F., \& Granger, C. W. (1987). Co-integration and error correction: representation, estimation, and testing. Econometrica: journal of the Econometric Society, 251-276.

Egwaikhide, F. O. (1993). IMF World Bank programme in Nigeria: an assessment of the performance of external trade. Applied economics and economic policy: In honour of Professor Emmanuel C. Edozien, 88.

Goldstein, M., \& Khan, M. S. (1976). Large versus small price changes and the demand for imports. Staff Papers, 23(1), 200-225.

Imoughele, L. E., \& Ismaila, M. (2015). The impact of exchange rate on Nigeria non-oil exports. International Journal of Academic Research in Accounting, Finance and Management Sciences, 5(1), 190-198.

Johansen, S. (1988). Statistical analysis of cointegration vectors. Journal of economic dynamics and control, 12(2-3), 231-254

McKenzie, M. D. (1999). The impact of exchange rate volatility on international trade flows. Journal of economic Surveys, 13(1), 71-106.

McKenzie, M. D., \& Brooks, R. D. (1997). The impact of exchange rate volatility on German-US trade flows. Journal of International Financial Markets, Institutions and Money, 7(1), 73-87.

Ojo, O. (1978). A quarterly econometric model of the Nigerian economy: Some preliminary estimates. Ife Social Science Review 1(2): 149-65.

Omolola, A. (1992). Rubber and Fisheries Industries under the Structural Adjustment Programme. NISER Monograph Series, No. 2.

Osagie, E. (1985). An operational econometric model of the Nigerian economy: Some preliminary estimates. Ife Social Science Review. 1(2), 149-65.

Osuntogun, A., C.C. Edordu and B.O. Oramah. (1993). Promoting Nigeria's non-oil export: An analysis of some strategic issues. Final report. African Economic Research Consortium, Nairobi, Kenya.

Oyejide, T. A. (1986) .The Effects of Trade and Exchange Rate Policies on Agriculture in Nigeria. Research Report 55, International Food Policy Research Institute, Washington D.C.

Ozturk, I. (2006). Exchange rate volatility and trade: a literature survey. International Journal of Applied Econometrics and Quantitative Studies, 3(1).

Pesaran, M. H., Shin, Y., \& Smith, R. P. (1999). Pooled mean group estimation of dynamic heterogeneous panels. Journal of the American Statistical Association, 94(446), 621-634.

Sauer, C., \& Bohara, A. K. (2001). Exchange rate volatility and exports: regional differences between developing and industrialized countries. Review of International Economics, 9(1), 133-152.

Yinusa, D. O. (2008). Exchange Rate Volatility, Currency Substitution and Monetary Policy in Nigeria (No. 16255). University Library of Munich, Germany.

Yinusa, D. O., \& Akinlo, A. E. (2008). Exchange rate volatility and the extent of currency substitution in Nigeria. Indian Economic Review, 161-181. 